\title{
Determinants of Agroecological Practices Adoption in the Sudano-Sahelian Zone
}

\author{
Aboubacar Coulibaly1,2*, Mikael Motelica-Heino', Edmond Hien ${ }^{2,3}$ \\ ${ }^{1}$ University of Orleans, Orleans, France \\ ${ }^{2}$ University Ouaga I Pr Joseph Ki-Zerbo, Ougadougou, Burkina Faso \\ ${ }^{3}$ Research Institute for Development, Ouagadougou, Burkina Faso \\ Email: *coulouby@yahoo.fr
}

How to cite this paper: Coulibaly, A., Motelica-Heino, M. and Hien, E. (2019) Determinants of Agroecological Practices Adoption in the Sudano-Sahelian Zone. Journal of Environmental Protection, 10, 900-918. https://doi.org/10.4236/jep.2019.107053

Received: May 31, 2019

Accepted: July 1, 2019

Published: July 4, 2019

Copyright (c) 2019 by author(s) and Scientific Research Publishing Inc. This work is licensed under the Creative Commons Attribution International License (CC BY 4.0).

http://creativecommons.org/licenses/by/4.0/

(c) (i) Open Access

\begin{abstract}
Under the combined effect of both climatic and anthropogenic factors, agroecosystems and especially arable soils undergo a worrying and fast degradation in the Sudano-Sahelian zone of Western Africa threatening its socio-economic development. Food systems need to be better managed to be more resilient, to increase agricultural production, while conserving natural resources and biodiversity. Agroecological practices alternatively with traditional cultural techniques have been locally experimented to cope with local pedoclimatic constraints such as weak (low) soil fertility and climate change, increasing food demand and economic conditions. Our work aims at by taking stock of agroecological knowledge as well as the determinants of their adoption with small-scale farmers in Eastern Burkina Faso. A survey (48 farmers) was conducted in Sampieri (Kantchari district), and Logit model was used to determine equations for agroecological practices adoption. Results show that traditional production practices for millet-bean cultural systems are gradually being replaced by those of agroecological. In fact, $60.4 \%$ of producers have participated in at least one agroecological training session and $60.8 \%$ of producers are interested at least in one agroecological topic. The most adopted and practiced techniques were superficial plowing, stone-rows, zaï and compost, single or in combination ( $60 \%$ of the producers). Determinants of these practices adoption were the increased crop yields, improved of producers' incomes, the provision or otherwise of material and human resources and training. Additionally, variables such as training, possession of agricultural equipment were positively correlated to the adoption of agroecological practices while illiteracy impacts negatively and significantly this adoption. Moreover, agroecological practices had a significant effect on grain and straw yields of sorghum, thus confirming producers' claims about the improvements in production observed following the adoption of these practices.
\end{abstract}




\section{Keywords}

Agroecological Practices, Adoption, Determinants, Traditional Practices, Burkina Faso

\section{Introduction}

Burkina Faso is a Sudano-Sahelian country with an agricultural vocation. In fact; this sector occupies almost $90 \%$ of the population and contributes to $40 \%$ of the Gross Domestic Product (GDP). Therefore, the country economy's structure is mainly based on its land and/or natural resources (soils, forests, wildlife and waters). Unfortunately, due to the combined effect of climatic and anthropogenic factors, particularly agricultural practices [1], this capital is undergoing soil degradation (water and wind erosion, soil surface encrustation ...) which threatens the socio-economic development of the country. According to [2], about $24 \%$ of Burkina Faso's arable lands are severely degraded. This situation coupled with the fact that soils in the country are generally deficient in nutrients, especially $\mathrm{N}$ and $\mathrm{P}$ [3], threatens to undermine the quality of the natural environment and food security in the medium and long term.

The eastern region of Burkina Faso, considered as an area with high forest and potential reserve, is no exception to this rule. The decline of rainfall, the influx of cattle in search of pasture, demographic and land tenure pressure, etc. have resulted in accelerated degradation of natural resources, particularly soil fertility [4]. The extension of cotton production and sesame in this region also has contributed to the degradation of arable land and natural resources. The extension of cotton cultivation in western and central Africa has indeed adverse consequences such as climate change, biological diversity declining and accelerating land degradation [5].

Human action is thus a major influence on the problem of natural resources management [6] and it is also clear that the severe degradation of natural resources in the eastern region of Burkina is linked to agriculture [1].

To cope with the pronounced degradation of local soils, producers associations with the support of their partners have promoted agroecological practices. Based on the suitable use of local resources, agroecology aims to integrate into its practice, several parameters of ecological management of the cultivated area, in order to reconcile productivity, sustainable management of natural resources, food security and human development while preserving the health of populations [7] [8]. These practices would thus not only restore soil fertility, but also ensure a real integration of agro-sylvo-pastoral practices enabling local populations to benefit in the short, medium and long term. Producers have developed agroecological learning practices to secure their farms including, the use of stone-rows, zaï, production and use of compost, etc. [9] [10]. Their positive impact on soil physical, chemical and biological characteristics has been demon- 
strated [10] [11] [12] [13] [14]. However, it is important to identify the determinants of the adoption of these agro-ecological practices together with their impact on crop production in comparison with traditional production practices for a better orientation of the actions. The objective of this study was thus to identify and describe agro-ecological practices promoted in the field, to imbibe peasant perceptions of the problem related to soil management and to identify social, technical and economic determinants of the adoption of these practices for millet-bean cultural systems on tropical lixisoils.

\section{Material and Methods}

\subsection{Study Area}

Located between $12^{\circ} 26^{\prime} 31.7^{\prime \prime}$ latitude and $001^{\circ} 20^{\prime} 41.6^{\prime \prime}$ longitude in the extreme east of Burkina Faso, Sampiéri (district of Kantchari) is one of the 232 villages of the province of Tapoa (county town Diapaga). It is located about $150 \mathrm{~km}$ from the town of Fada N'Gourma and $20 \mathrm{~km}$ from the municipality of Kantchari (border Burkina-Niger). The village has about 1300 inhabitants [15], mostly Gourmantché (farmers) but with a strong Fulani community (breeders). Agriculture practice is, therefore, the main activity. Family farming with a small plot per producer (2.37 ha) is strongly developed. Food production (sorghum, millet and maize), the main mode of production, has (contributed) to the development of cash crops with the installation of cotton and sesame.

The climate is Northern Sudanian type with an average annual rainfall between 800 and $1000 \mathrm{~mm}$ [4]. On the geological stand Sampieri is on bedrock resulting from the alternation between birrimian furrows and granitic terrains [16]. In addition, the village is located in an area where soils are mostly plinthosoils and lixisoils [17].

\subsection{Data Collection and Processing}

\subsubsection{Choice of Target Actors}

The choice of Sampieri is justified by the presence of the Loos N'gourma NGO since 1981 in various fields of development including health and education at the start. Since 2004 this collaboration has also been focused on sustainable agriculture with the promotion of practices known as agroecological. To this end, an agroecological center was built in Sampieri and local actors in particular AVAPAS (trainers association) as an extension and the Association Fiimba as beneficiary are involved in this activity. Fiimba is a farmers association aiming the implementing of agroecological techniques.

As far as our agronomical survey is concerned, the choice was made by a sample of so-called model producers (according to Fiimba are producers interested and open to technological innovations) throughout the slope of the watershed. Thus, about 15 model producers were interviewed and surveyed in the first step. Secondly, a random draw was performed to give the chance to meet producers who have been trained in agroecology and those who have not (traditional far- 
mers) and to survey them in Sampieri and its surroundings. In this second step, about 33 producers were met including 20 producers who did not participate in agroecology training session. Survey was conducted during raining season while farmers were in full production activity.

The same data collection sheet was used for the following step. In total, 48 eight producers were surveyed through semi-structured interviews.

\subsubsection{Model Used}

One of the objectives of our study is to find determinants of the adoption of agroecological practices for millet-bean cultural systems on tropical lixisoils. To reach this goal, we used logit modeling [18]. The Logit model, which is generally used in studies of the adoption of soil and water conservation techniques [19] [20], was used to determine equations for the adoption of agroecological techniques in our study. Two major properties made the interest of the logistic distribution function in the modeling of discrete choices. This includes its interval which is reduced to $[0,1]$ and the possibility of being linearized by a logarithmic transformation. The explanatory variables are shown in Table 1 . These variables chosen were taking into account literature and similar studies on agroecological practices adoption of completed with statistical analyzes.

Table 1. List of the explanatory's variables for the model adoption.

\begin{tabular}{|c|c|c|}
\hline Variable & Type & Measures \\
\hline Age & Quantitative & Determines the age of the head of household \\
\hline Sex & Qualitative & Refers to the sex of the head of household \\
\hline \multicolumn{3}{|l|}{ Level of education } \\
\hline \multicolumn{3}{|r|}{$D^{2}$} \\
\hline Primary & Qualitative & Determines school level of the head of household \\
\hline \multicolumn{3}{|l|}{ Secondary } \\
\hline Number of assets & Quantitative & $\begin{array}{l}\text { Measures the number of workers in activity in the plots of the } \\
\text { head of household }\end{array}$ \\
\hline Equipment & Quantitative & $\begin{array}{l}\text { Determines whether the household has material for } \\
\text { composting and other activities such as Zaï and Stony-rows. } \\
\text { It is set to } 1 \text { if yes and } 0 \text { otherwise }\end{array}$ \\
\hline $\begin{array}{l}\text { Training in } \\
\text { agroecology }\end{array}$ & Quantitative & $\begin{array}{l}\text { Indicates whether or not the household has had training on } \\
\text { the implementation of the technique. It is set to } 1 \text { if yes and } 0 \\
\text { otherwise }\end{array}$ \\
\hline Number of cattle & Quantitative & Refers to the number of cattle belonging to the household \\
\hline $\begin{array}{l}\text { Number of } \\
\text { smallruminants }\end{array}$ & Quantitative & $\begin{array}{l}\text { Refers to the number of small ruminants (goats and sheep) } \\
\text { belonging to household }\end{array}$ \\
\hline $\begin{array}{l}\text { Perception of } \\
\text { agroecology }\end{array}$ & Qualitative & $\begin{array}{l}\text { Indicates the perception of the head of household on the } \\
\text { impact of the technique on yields. It takes the value } 1 \text { if good } \\
\text { perception and } 0 \text { otherwise }\end{array}$ \\
\hline Area & Quantitative & Refers to the total area exploited by the household \\
\hline
\end{tabular}


Adoption was defined as the acceptance of the producer to use one of the agroecological practices regardless of the number of people and practices. The decision to adopt is considered as a qualitative dependent variable in a regression with a value of 0 or 1 . The logit model is characterizing the adoption by a sample of producers is specified as follows in Equation (1) [18] [21].

$$
P i=E(Y i)=F(\alpha+X i \beta)=\frac{1}{\left(1+\mathrm{e}^{\alpha+X i \beta}\right)}
$$

Equation (1): Logit model equation where the index " $i$ " indicates the $i$-th observation in the sample, $P i$ is the probability that an individual faces a given choice $Y i$, e is the basis of the natural logarithm, $x i$ is a vector of the exogenous variables, $\alpha$ is a constant and $\beta i$ are coefficients associated with each explanatory variable $X i$ to be estimated.

\subsection{Evaluation of Crop Yield}

To compare the farmers' perceptions of the improvement of yields to the reality of the fields, a performance evaluation was carried out as a result of the survey. We chose to evaluate the yields of white sorghum (local variety: itchiori en greedy language) which is the main speculation of the area. Thus, the choice fell on the plots of model peasants belonging to the 10 model producers of the preliminary survey. The treatments selected were the following:

- Zaï + Stony-Rows + Compost $(\mathrm{Z}+\mathrm{CP}+\mathrm{C})$;

- Stony-Rows + Compost $(\mathrm{CP}+\mathrm{C})$ and;

- Absolute control (TA): without composting or agroecological treatment corresponding to the traditional farming practices of the study zone.

Yield squares meter were set up in plots based on identified practices. It was consisted to install into the fields before the harvest some squares materialized with stakes and string. The square has been fixed at $5 \mathrm{~m}$ on the side, which makes it possible to measure the angles of $90^{\circ} \mathrm{C}$ easily. Thus, a square represents $25 \mathrm{~m}^{2}$ and by extrapolation, the yields per hectare are subsequently calculated. Thus, at harvesting, the ears and the straw are separated and after threshing the weighting was made using a hook scale.

\subsection{Statistical Analysis}

Statistical analyzes were done using SPSS 20 software for the survey data. Comparisons were done using the Turkey test at the 5\% threshold. The econometric analysis (Logit model) as well as the correlation test of the variables was conducted using STATA 11 the software.

\section{Results}

\subsection{Soil Fertility and Farmers Perception of Soils}

At Sampieri (village of Sampieri and surrounding) $98 \%$ of the population are mainly farmers and around $2 \%$ of the producers encountered have agricultural 
production as a secondary activity. These producers are almost entirely engaged in agriculture activity type family-farming characterized by small areas with an average of 2.37 hectares. Species commonly produced are sorghum, maize, cowpea and millet although there has been a rise in cash crops such as sesame and, more rarely, cotton.

Soils are considered like "a somewhat fertile" by all the producers met (100\%). Moreover, the state of degradation (erosion of soil) is perceived as a worrying phenomenon in this zone. Beyond the fact that $90 \%$ of producers consider their agricultural land degraded and soil fertility unsatisfactory; our study showed soils in places completely naked and also unproductive without appropriate farming practices. Moreover, the sandy-loam texture of these soils with very low structure stability shows a surface encrustation visible on the soil as soon as rains are over.

\subsection{Traditional Production Practices}

The calling "traditional practices" means those practices of farmers before the promotion and the new knowledge acquired about agroecology in the area by the association Fiimba (framework of our study) and other actors. Some of the traditional practices as well as agroecological practices coexist in the field among both trained and untrained producers. It should also be noted that some so-called agroecological practices also existed before the promotion of agroecology.

The most popular traditional tillage practice was scraping. This action, consisting of a superficial scraping of the soil top layer $(5-15 \mathrm{~cm}$ ) with daba (traditional chiseling hand tool) and pickax, appeared to be practiced by $64.6 \%$ of the producers (Table 2). In addition, about $21 \%$ of farmers saw with no specific tillage (zero tillage). The reasons for common scraping and zero plowing practices are basically the lack of adequate tools and means to modernize farms. Additionally to these two practices, some farmers (about 15\%) practiced plowing with a donkey plow to improve yields and facilitate other rural work.

As for organic fertilization, manure (stables, poultry houses, etc.) is the main product used by producers to improve the quality of their soils. It is produced from the own breeding of nearly $50 \%$ of the producers and is brought to the soil without any additional input or processing. About $8.3 \%$ of producers complete the use of crop residues with this manure. However, it is important to notify that $43.8 \%$ of producers produce on their plots without any external organic input (Table 2).

As for mineral fertilization, it is almost non-existent in the Sampieri area. Only $2 \%$ of producers used mineral fertilizers (NPK only) as a complement to organic fertilization.

Concerning cultural associations, we observed mainly Sorghum/Millet and Cowpea associations. Despite the state of fertility/degradation of agricultural soils no specific measures for soil and water conservation/soil protection and restoration had been adopted by the producers. 
Table 2. Evolution of agricultural practices before and after agroecology introduction.

\begin{tabular}{lccccc}
\hline \multirow{2}{*}{ Agroecological practice } & \multicolumn{2}{c}{ Before } & \multicolumn{2}{c}{ After } \\
& & \multicolumn{2}{c}{ agroecological training } & \multicolumn{2}{c}{ agroecological training } \\
\cline { 3 - 6 } & Superficial plowing & 7 & 14.6 & 32 & 66.7 \\
\hline \multirow{2}{*}{ Soil Tillage } & Zero tillage & 10 & 20.8 & 3 & 6.3 \\
& Scraping & 31 & 64.6 & 13 & 27.1 \\
& Manure & 23 & 47.9 & 8 & 16.7 \\
\multirow{2}{*}{ Fertilizer } & Compost & 0 & 0 & 22 & 45.8 \\
& $\begin{array}{c}\text { No fertilization/No } \\
\text { crop residues }\end{array}$ & 25 & 52.1 & 18 & 37.5 \\
\hline
\end{tabular}

Before agroecological training is the period since the first cultivation and the year 2006 corresponding to the beginning of agroecological practices. After agroecological training corresponds to the period between 2006 which is the beginning of practices and 2014 which corresponds to the starting of our investigations.

\subsection{Agroecological Practices}

In spite of all efforts done to improve agricultural production, expected results were below according to the producers in the natural conditions of Sampieri. Major difficulties encountered in recent years by the producers included rainfall decline and soil poverty. This required corrective measures either by the efforts of the producers themselves or by the intervention of various actors for the promotion of good agricultural practices. Our survey revealed that over to Fiimba other actors such as the Tin Tua association (non-governmental development organization working in the Gulmu) which means in gulimancema "Let's develop ourselves"), the Burkina Faso Fiber and Textile Society (Sofitex) and Support Program for Local Development in Eastern Burkina (ADELE) got some punctual and/or selective actions in the area. The enthusiasm of the farmers expresses the real need to improve practices. In fact, $60.4 \%$ of the producers investigated were trained in agroecology to some extent. The other producers interviewed have not been trained either due to the lack of information or time claim to see the clear difference between their activity and those of others; but seem very interested in further training sessions.

\subsubsection{Training Topics}

Producers have been taught on various topics during training session. These included: "the effect of plowing on soil, cropping patterns, cultural associations, fallowing, stony rows, zaï direct seedling, composting, agroforestry, etc."

Over the farmers coming from the association Fiimba, all producers of the village of Sampieri interested to develop the techniques could be beneficiary of the training topics. Many session of training have been organized by this association with the support of experts including those of AVAPAS. The topics mentioned above were taught both in theoretical and practical. The goal was to show the farmers the different techniques, to demonstrate their implementation in the 
field and to show the effects of these practices on the characteristics of the soil and on the production yields.

\subsubsection{Level of Actual Adoption of Agroecological Practices}

Our investigations show that $60.8 \%$ of the producers surveyed apply at least one of the topics taught during the training sessions. Among these producers, it appears that about $13 \%$ have not received any training. Therefore; it seems that the "oil stain" effect has given fruit because these producers have simply benefited from the expertise of nearby producers who have been trained. Among the $31.4 \%$ of producers met, $11.8 \%$ were trained and they do not apply the agroecological themes taught due mostly to the lack of material and required numbers of person affordable to work. At the question related to what can hinder the adoption of agroecological practices, all actors asserted that the work painfulness combined with the lack of material support and the workforce are the mains difficulties that which can justify the give-up of good agroecological practices.

\subsubsection{Agroecological Practices Adopted \\ \& Plowing}

Results showed that $67 \%$ of farmers are currently using superficial plowing on their farms, i.e. a growth rate of $52 \%$ compared to the pre-training period (Table 2). However it should be noted that $14.6 \%$ of farmers already practiced plowing before the promotion of this practice in the area.

To facilitate the adoption of these techniques, producers benefited of financial support of the association Fiimba after the training sessions for the acquisition of plow and donkey. Thus, $60 \%$ of the trained producers received this support up to an amount of 86,000 FCFA refundable in three tranches and would benefit from agricultural equipment (plow + donkey).

\section{Composting}

$46 \%$ of producers were engaged in the manufacture and use of aerobic compost (Table 2). This consisted of digging a pit ca. $3 \times 3$ meters by 1 meter deep (stabilized with cement or not) and gradually filling it with the following organic and mineral substrates: ash from kitchen, straw/crop residues/household waste, animal discharge. Whenever we add a different substrate we proceed to a watering until filling the pit. After filling, the whole is returned every 15 days at least 4 times to ensure that the compost produced is mature and of good quality. Other producers continue to use manure and/or crop residues without processing. In this group of producers, about $31 \%$ have received training, but for reasons mentioned above, they have not yet engaged in the dynamics of the manufacture and use of compost. Moreover, despite the standards taught in terms of dosage in the plots, the producers still bring the compost accordingly to the available matter on all plots without prior calculation. It follows from our investigation that the doses (quantity) brought vary from 1.5 to about 6 tons per hectare depending on the farms. Compost is usually deposited in heaps on the plots before spreading mostly in the month of May-June. As in the case of plowing, training groups 
have benefited from equipment to facilitate pit making, manufacture and transport of compost to the field. These lots consisted of a cart, a wheelbarrow, shovels, picks and forks that cost 200,000 FCFA money, refundable in three tranches as well.

\section{Cultural associations}

Although taught on agroecological practices, several cultural associations are common and ancestral practices in the area. Therefore it's difficult to cross a farm in the area without meeting biphasic or triphasic associations such as: sorghum/millet; sorghum/cowpea; millet/cowpea; sorghum/millet/cowpea and rarely corn/sorghum/cowpea. But, we can say that despite all the peasant perception of the cultural association has changed anyway. According to the farmers these traditional cultural associations are meaning today the diversification of production in connection with climatic change. Moreover, producers claim to benefit from positive effects of associations such as cowpea on cereals growth. Lastly cultural associations make it possible to harvest something whatever the difficulties encountered during the campaign.

\section{Stone-row and zaï}

One of the agroecological techniques most adopted in the area is the installation of stone-rows. Indeed $42 \%$ of the producers have put in their exploitation these stony ribbons in order to:

- avoid the transport of fertilizers and fine elements by runoff (according to $23 \%)$;

- halt water erosion by reducing runoff water (4\%);

- recover or restore abandoned/unproductive land (2\%);

- regularize the slope of the land (4\%).

According to the producers, this activity consists simply of dressing stones accordingly to contour lines (Figure 1). It's using is generally supplemented by organic fertilization which according to them allows optimizing the stony-rows. As for the zaii, stone-rows have been adopted by only $10 \%$ of the producers met. Zaï practiced on bare plots ("Zippelé") but curiously among some producers also on ordinary plots. Zaï consists of digging holes $20 \mathrm{~cm}$ deep and $40 \mathrm{~cm}$ in diameter and placing the excavated soil downstream (Figure 1). Thus, it makes it possible to optimize the recovery of run-off water. Also, note that in the area, there are no isolated zaï plots. This technique is combined with the placement of stony cords and the using of compost in the holes. However, in the image of the classical plots, the doses brought are hardly manageable.

\subsubsection{Producers' Perceptions of the Impact of Agroecological Practices}

This issue has been discussed with producers both in terms of effect on soil fertility and on agricultural yields. The effect of agroecological practices on soil fertility is considered good to excellent by all producers who practice these techniques. For further reflection they were also asked how they really appreciate it in the field. The answers seem rather vague but most of them revolved around the vegetative state and yields that would have improved over time thanks to 
these practices compared to the other plots cultivated traditionally and the years preceding their introduction. Field observations confirmed this statement. Indeed, the same variety of sorghum, sown on the same date, we can see the difference between the plants of the control and agroecological fields with a greater vegetative development of the latter (Figure 2). Compared to the average of the area and other nearby traditional producers, those who practice agroecology considered the yields as excellent. They reported average yields up to 1.5 to 3 tons/hectare for sorghum (about 0.8 tons/hectare on average); 2 tons/hectare for maize ( 1 ton/hectare maximum in normal average production); 0.8 ton/hectare for cowpea ( 0.4 to 0.5 ton/hectare on average) and 0.7 ton/hectare for sesame (0.6 ton/hectare on average) are recorded.

\subsubsection{Factors Affecting the Adoption of Agroecological Practices According to the Logit Model}

Before the econometric analysis, we conducted a correlation test to check the degree of resemblance (collinearity) of the various variables with the adoption rate of the practices. Results showed a strong correlation $(\mathrm{P}<0.05)$ between the adoption of practices $(\mathrm{Y})$ and the variables "equipment", "training on agroecology" and "producers perception" so that the model assimilates them to Y (Table 3). Thus we can assert that these variables are in our study sine qua none conditions for the adoption of at least one agroecological practice.

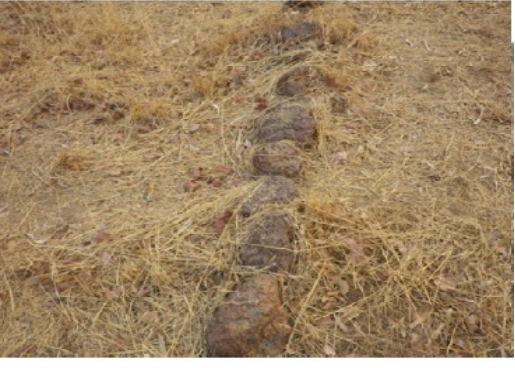

(a)

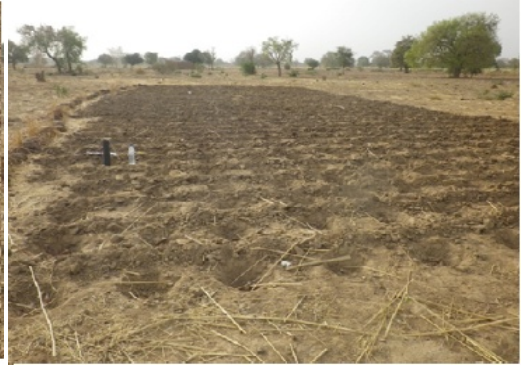

(b)

Figure 1. (a) Stone row for soil and water conservation. Belt of stones built on contours as an erosion control technique; (b) Zaï, a special form of culture in bunches of micro-basinswithuse of aerobic composting. The depth of the zail holes varies between 10 and $15 \mathrm{~cm}$.

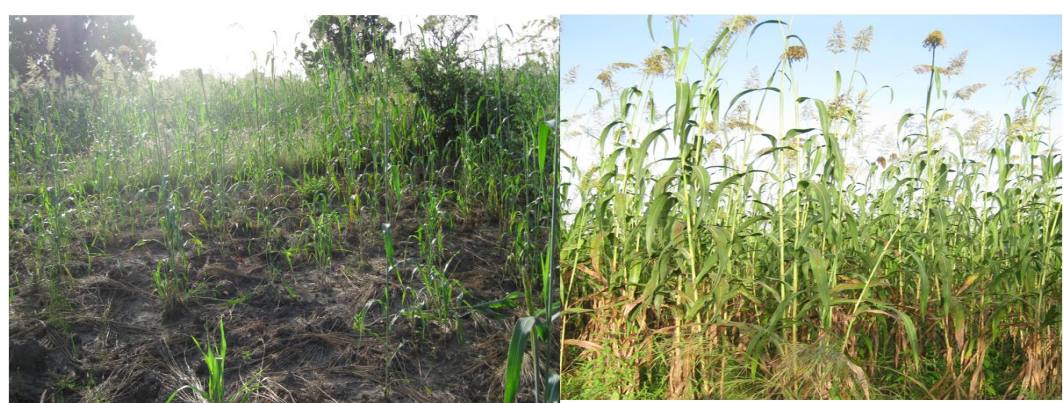

(a)

(b)

Figure 2. (a) View of a control plot (b) Agroecological plot. 
Table 3. Correlation test between variables and Y.

\begin{tabular}{ccccccc}
\hline & $\mathrm{Y}$ & Sexe & MatTraSol & $\begin{array}{c}\text { Mat } \\
\text { Compostage }\end{array}$ & $\begin{array}{c}\text { Forma } \\
\text { Agroeco }\end{array}$ & $\begin{array}{c}\text { Impact } \\
\text { AgroecoSol }\end{array}$ \\
\hline Y & 1.0000 & & & & & \\
Sexe & 0.2495 & 1.0000 & & & & \\
MatTraSol & $\mathbf{0 . 9 5 6 0}$ & 0.2335 & 1.0000 & & & \\
MatCompostage & $\mathbf{0 . 9 5 6 0}$ & 0.2335 & 1.0000 & 1.0000 & & \\
FormaAgroeco & $\mathbf{0 . 7 3 6 7}$ & -0.0899 & 0.7810 & 0.7810 & 1.0000 & \\
ImpactAgroecoSol & $\mathbf{0 . 8 6 2 5}$ & 0.2665 & 0.9129 & 0.9129 & 0.6928 & 1.0000 \\
\hline
\end{tabular}

Logit results also show that most of the variables examined did not have the expected effects. Only the variables "level of education" with its subcomponent none = Illiterate affects $Y$ negatively and significantly to $5 \%$ (Table 4). Other variables such as "age", "number of assets", "number of cattle" (NbrCattle), "number of small ruminants" (NbrSmaRumun) and "area" did not affect the adoption of agroecological practices.

\subsubsection{Determinants of the Adoption of Agroecological Practices in Sampieri}

Therefore it is clear from our analysis and from answers of the producers we met, that several factors (Figure 3) seem to be the determinants for a producer to be involved in agroecology in Sampieri. These are mainly:

the prospects for future improvements in crop yields;

$>$ the desire to increase incomes;

$>$ participation in agroecology training;

ease/difficulty of technology implementing;

$>$ disposal/possession of material and human resources.

Beyond these factors, it must be recognized that for these producers a number of difficulties can hinder the adoption of agroecological practices. In fact, to the question of what can dampen the adoption of agroecological practices all actors asserted that they were:

painfulness of combined work;

$>$ lack of material support and labor;

> lack of training and/or retraining of the different actors.

\section{Effect of Practices on Grain and Straw Yields of Sorghum}

For $\mathrm{Z}+\mathrm{SR}+\mathrm{C}$ and $\mathrm{SR}+\mathrm{C}$ treatments, the productivity was improved and the values obtained were always higher than those of the absolute control (Figure 4). In fact, the average grain yield is $1.73 \mathrm{t} \cdot \mathrm{ha}^{-1}$ for $\mathrm{Z}+\mathrm{SR}+\mathrm{C}$ and $1.78 \mathrm{t} \cdot \mathrm{ha} \mathrm{a}^{-1}$ for $\mathrm{SR}+\mathrm{C}$ while the absolute control is $0.695 \mathrm{t} \cdot \mathrm{ha}^{-1}$. Statistical analysis with the Tukey test showed that there are significant differences between the agroecological treatments $\mathrm{Z}$ $+\mathrm{SR}+\mathrm{C}$ and $\mathrm{CP}+\mathrm{C}$ and the control $(\mathrm{p}<5 \%)$.

Like the grain yield, the straw production of the $\mathrm{Z}+\mathrm{SR}+\mathrm{C}$ and $\mathrm{SR}+\mathrm{C}$ treatments is always greater than that of the absolute control (Figure 4). The mean 
average values are: $6.23 \mathrm{t} \cdot \mathrm{ha}^{-1}$ for $\mathrm{Z}+\mathrm{SR}+\mathrm{C} ; 6.025 \mathrm{t} \cdot \mathrm{ha}^{-1} ; \mathrm{SR}+\mathrm{C}$ and $3.3 \mathrm{t} \cdot \mathrm{ha}^{-1}$ for the absolute control. The analysis of variance showed that there are significant differences between the agroecological treatments and the absolute control at the $5 \%$ threshold according to the Tukey test.

Table 4. Result of the econometric analysis of the adoption of agroecological practices in eastern Burkina (regression coefficients).

\begin{tabular}{cc}
\hline Variables & Coefficient of regression \\
\hline âge & 0.0312039 \\
Aucun (illettré) & $-2.368065^{*}$ \\
Actifs & 0.1011208 \\
NbreBovins & -.0490591 \\
NbrePETRUMIN & -.0285506 \\
Superficie & 0.4752546
\end{tabular}

* = significance at $P<0.05$.

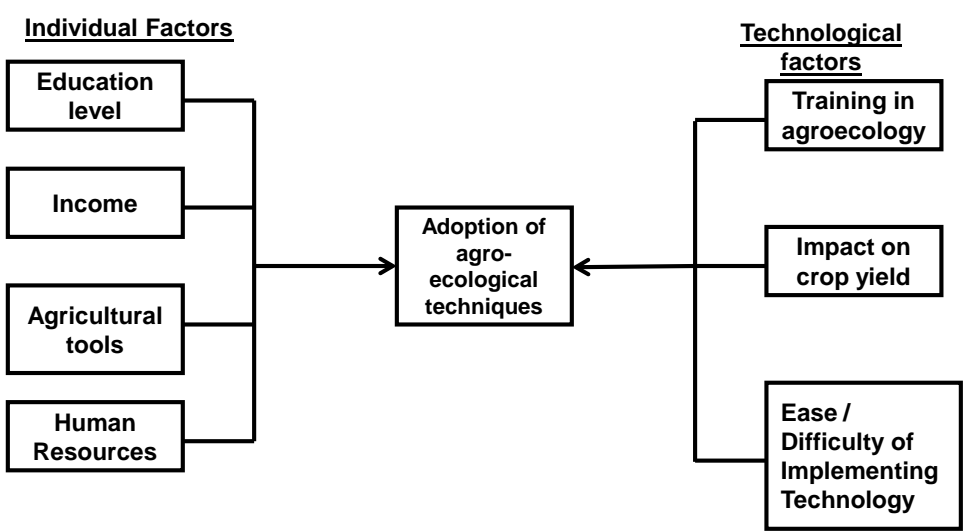

Figure 3. The main determinants of agroecological practices adoption in Sampieri.

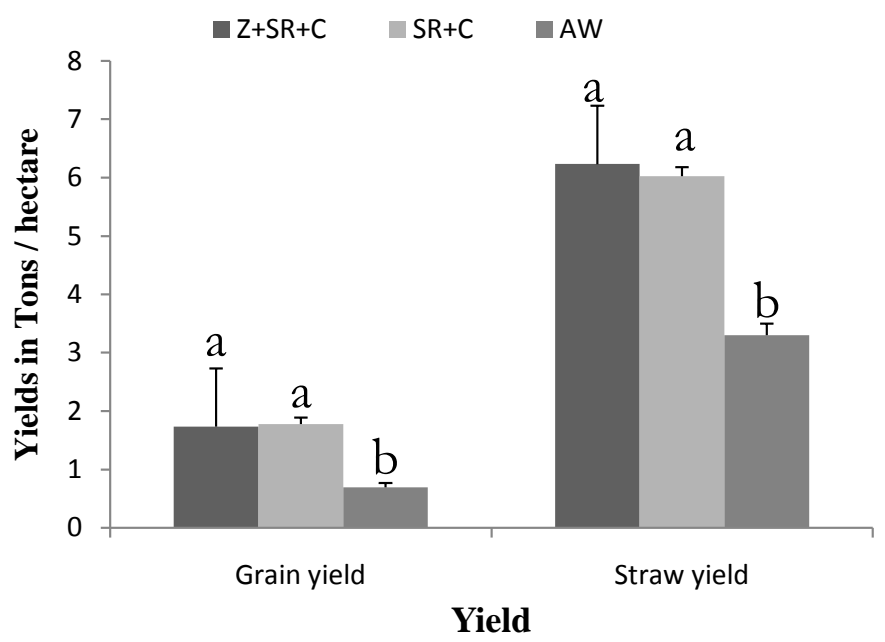

Figure 4. Sorghum grain and straw yields (histograms with the same letters "a" or "b" are not significantly different at $5 \%$ ). 


\section{Discussion}

Several agroecological practices have emerged in the agricultural communities in Sudano-Sahelian Africa as a fashion phenomenon or as a corrective necessity of natural or difficulties induced by the actors themselves. The innovative agroecological practices (zaï, stony-rows) in our study area appear however to be traditional in some other areas of the country such as the North where several studies in both controlled and farmer environment have been conducted with positive [10] [13]. Our investigations showed that $60.8 \%$ of the producers practice at least one of the techniques taught to them. This rate is for instance significantly higher than those in Cameroon (54\%) for the adoption of anti-erosive techniques [22]. $60 \%$ of the producers have adequate agricultural equipment (plow + donkey). Admittedly this equipment rate is below the average of $77 \%$ found by [1] in the same region of eastern Burkina Faso, but it allowed these farmers to perform superficial tillage and thus, to reduce the labor burden and hardship insofar as they appear to be important factors in the adoption of agroecological techniques. In fact, the resulting practice of plowing remains one of the major results of the project's (BioSol) intervention, given the effect and adoption that followed. The use of the harness culture widely acquired by the producers is a salute because lighter than the motorized traction on the one hand and less painful than scratching on the other hand. This type of instrument seems to well respond to the pedoclimatic conditions of the zone [23].

As for the crop associations, they seem to have not evolved very much between before and after the introduction of agroecology except that the cowpea tends to take a little more important place. Moreover, the perception of the producers of what little brought a good association changed with the introduction of agroecology and differences in training and awareness. However, these associations remain Sorgho-dominated due to crop and cultural habits but also and above all by the need to satisfy food and nutritional needs of the families. Cultural associations are practiced in the Sudano-Sahelian zone of Africa for traditional reasons and the need for food security through diversification [24]. However, a study carried out in Ivory Coast [25] showed that some associations (yam and legumes) led to lower yields than individual crops. Therefore, It may $t$ be important to push further investigations to reassure producers about the benefits of this practice, which is the best shared and most recognized traditional and cultural practice in the area.

Organic amendments (mainly compost and manure) done to the fields of the different producers have changed with the promotion of agroecology. However, a high rate of peasants does not apply such input or simply leave some crop residues on the fields. Although composting seems to be adopted by about $50 \%$ of the producers surveyed, production conditions need to be improved, all of which can lead to questions related to the quality of the compost comings from it. In fact, the shining description that emerges from interviews often contrasts with reality when pits for the manufacture of compost are observed However, 
amendments to the field help in any case to increase the organic soil stock, maintain its structural stability and increase soil and water permeability to air and water [26]. In addition to being a source of nutrients such as N, P, K, S and several micronutrients, organic matter improves the physical, chemical and biological properties of soils and thus agricultural productions [27]. However, composting, which is an essential part of agroecology, seems to be more appropriate than manure in the field. In fact, the $\mathrm{N}$ contained in manure is mainly ammoniacal and given the conditions of deposition and use in our areas, manure can lose this important compound in our soils [28] unlike compost in which it is essentially in organic form and gradually make available to the plants in tropical zone. [29] showed that the effect of compost is significantly better than manure on soil physical and chemical characteristics.

Water and soil conservation techniques previously almost non-existent in the area have finally imposed themselves as solutions to the various problems highlighted by the producers. Thus, there is a noticeable presence of stony-rows and, to a lesser extent, zaï. We also note that all the plots arranged in zaï are also managed in stony-rows. The predominance of stony rows may arise from the fact that this development is most often based on community work and remains as long as possible with visible effects in relation to grass strips. As for the low adoption rate of zaï, this can be explained by the fact that although the land is often degraded and not very fertile in the zone, the totally bare lands ("zippelé") that are the origin of this technology in the northern part of Burkina Faso are not very well widespread in the area. These technologies have been the subject of several studies in similar pedoclimatic conditions and have shown a positive contribution to agricultural yields [10] [13] [30]. Moreover, beyond their agronomic performances, they are easily adopted by small producers [10] [31].

Different factors may influence the acceptance and/or adoption of new agricultural techniques in a given area. Our results show that there is a positive correlation between the probability of adopting an agroecological practice and the variables of agricultural material, soil work and composting, agroecology training and the producer's perception of the effect of these practices on the soil fertility. Moreover the fact that a household head is illiterate has a negative and significant impact on the adoption of agroecological techniques. Although the level of education as a whole has not been investigated, these results are consistent with those found by [32]. These authors showed that factors such as education level of the household head positively affected the adoption of water and soil conservation technology in northern part of Ethiopia. However [23] found that the level of education had no influence on the adoption of anti-erosion technique in Cameroon. Consequently, the adoption of soil and water conservation practices depends on the region and socio-economic characteristics of the producers [33] [34] and also the short-term benefit guides the choice of producers [35].

Yield is the material expression of the water and mineral nutrition of sorghum 
and remains the most prominent parameter for expressing the performance of production techniques [36]. The joint use of compost, stone-rows and zaï resulted in an increase of sorghum grain yield of about $146 \%$ and that of compost and stone bundles resulted in a yield increase of $155 \%$. These results are superior to those of [13] who found in the north of the country yield increases of $106 \%$ with the combination of compost and stony cords.

On the other hand [14] obtained in the west an increase of the order of 300\% to $500 \%$ respectively for Zaï + Stone-rows and Zaï. Admittedly, it is difficult in our study to dissociate the individualized contribution of the different elements (Zaï, stony-rows and with or without compost) but the sedimentation of the OM particles contained in the run-off water [37] thanks to the stony-rows and Zai on the one hand and the contribution of compost on the other hand could explain this yield increasing compared to the control.

Indeed, [38] stated that OM intake would lead to an improvement in the total number of ears per hectare and increase the weight of 1000 grains and therefore the yield. It follows an improvement of the productions and even an induction of a rear effect observed the following years [39]. It also appears that the implementation of water and soil conservation techniques without nutrients does not lead to a significant improvement in yield, especially in years of good rainfall [13] [31]. The results of the analysis thus confirm the affirmations of the farmers on the perception and the effects of the agroecological practices on the returns of the cultures. It can therefore be concluded that, in accordance with the assertion of the producer, there are also positive correlations between the physical and chemical characteristics of soils and yields, which show the importance of planting practices. In addition to the results obtained by [40], we have in our study established positive relationships between microbial biomass and grain and straw yields of sorghum.

\section{Conclusions}

The typology of agricultural holdings in Sampieri area shows a traditional agriculture that was until then rudimentary and dominant in the family farming with a small area (2.37 hectares on average) per person and producing little income. It is also apparent that crop and livestock production coexists in the area as most of the farms are also breeders with several heads of animals. Fallows which allowed the recovery of agricultural lands have gradually disappeared either because of the extension of the area or because of the demographic pressure.

In response to this challenge the implementation of agroecological projects of increasing production and protecting natural resources has been followed by development partners. Of all the producers interviewed, $60.8 \%$ adopted at least one of the agroecological practice taught indicating a good adoption rate. The use of organic amendment (manure and/or compost) is widespread among producers, although production and utilization standards can be further improved. Potentially/negatively influencing factors have been identified and it 
appears that some key-factors such as participation in training and obtaining agricultural equipment are strongly correlated with the likelihood of techniques adoption.

However, objective limits can be found at the end of this study. First of all the data used is a one-off survey and it seems desirable to carry out and secondly one on a target group over a long period of at least 3 years. It will also be possible to evaluate crop yields and the impact of these practices on producers' incomes and on soils fertility in the area.

\section{Acknowledgements}

We thank all farmers from Sampieri for helping us for the information provided during the agronomic survey. We also thank the Department of Cultural Cooperation and Action of the French Embassy in Burkina Faso and Campus France for the financial support provided in part to this study. Finally, we thank the BIOSOL project (Region Centre Val de Loire) for the initiation and the multifaceted support for the implementation and the conduct of this study.

\section{Conflicts of Interest}

The authors declare no conflicts of interest regarding the publication of this paper.

\section{References}

[1] Gomgnimbou, A.P.K., Savadogo, P.W., Nianogo, A.J. and Millogo-Rasolodimby, J. (2010) Pratiques agricoles et perceptions paysannes des impacts environnementaux de la cotonculture dans la province de la Kompienga (Burkina Faso). Sciences et Nature, 7, 165-175. https://doi.org/10.4314/scinat.v7i2.59960

[2] INERA (2000) Rapport sur les acquis scientifiques 1992-1999 du département gestion des ressources naturelles et systèmes de productions. (GRN/SP)/Ouagadougou (Burkina Faso).

[3] Dembélé, Y. and Some, L. (1991) Propriétés hydrodynamiques des principaux types de sol du Burkina Faso. Soil Water Balance in the Sudano-Sahelian Zone, 199, 217-227.

[4] PICOFA (2006) Stratégies de gestion de la fertilité des sols et des ressources naturelles dans la région de l'est du Burkina Faso. Rapport de l'étude de base relative à l'établissement de la situation de référence dans la zone d'intervention du PICOFA. Burkina Faso.

[5] Abba, A.A., Hofs, J. and Mergeai, G. (2006) Relever les défis environnementaux pour les filières cotonnières d'Afrique de l'Ouest et du Centre. Biotechnologie, Agronomie, Société et Environnement, 10, 351-359.

[6] Bationo, A., Kihara, J., Vanlauwe, B., Waswa, B. and Kimetu, J. (2007) Soil Organic Carbon Dynamics, Functions and Management in West African Agro-Ecosystems. Agricultural Systems, 9, 13-25. https://doi.org/10.1016/j.agsy.2005.08.011

[7] Altieri, M.A. (2002) Agroecology: The Science of Natural Resource Management for Poor Farmers in Marginal Environments. Agriculture, Ecosystems and Environment, 93, 1-24. https://doi.org/10.1016/S0167-8809(02)00085-3

[8] De Shutter, O. (2010) Rapport du Rapporteur spécial sur le droit à l'alimentation, 
Assemblée Générale des Nations Unies A/HRC/16/49.

[9] Mietton, M. (1986) Méthodes et efficacité de la lutte contre l'érosion hydrique au Burkina Faso. Cahiers ORSTOM, Série Pédologie, Paris, 22, 181-192.

[10] Sawadogo, H., Bock, L., Lacroix, D. and Zombré, N.P. (2008) Restauration des sols dégradés à l'aide du zaï et du compost dans le Yatenga (Burkina Faso). Biotechnologie, Agronomie, Société et Environnement, 12, 279-290.

[11] Bouzou-Moussa, I. and Dan Lamso, N. (2004) Le Tassa: Une technique de conservation des eaux et des sols bien adaptée aux conditions physiques et socioéconomiques des glacis des régions semi-arides (Niger). Revue de Géographie Alpine, 92, 61-70. https://doi.org/10.3406/rga.2004.2278

[12] Coulibaly, A., Hien, E., Motelica-Heino, M. and Bourgerie, S. (2018) Effect of Agroecological Practices on Cultivated Lixisol Fertility in Eastern Burkina Faso. International Journal of Biological and Chemical Sciences, 12, 1976-1992. https://doi.org/10.4314/ijbcs.v12i5.2

[13] Zougmoré, R., Ouattara, K., Mando, A. and Ouattara, B. (2004) Rôle des nutriments dans le succès des techniques de conservation des eaux et des sols (cordons pierreux, bandes enherbées, zaï et demi-lunes) au Burkina Faso. Sécheresse, 15, 41-48.

[14] Yaméogo, J.T., Somé, A.N., Mette, Lykke, A., Hien, M. and Nacro, H.B. (2013) Restauration des potentialités de sols dégradés à l'aide du zaï et des cordons pierreux à l'Ouest du Burkina Faso. Tropicultura, 31, 224-230.

[15] INSD (2008) Recensement général de la population et de l'habitation de 2006. Résultats définitif, Burkina Faso.

[16] Sattran, V. and Wenmenga, U. (2002) Géologie du Burkina Faso. Czech Geological Survey.

[17] WRB (2014) World Reference Base for Soil Resources 2014. World Soil Resources (Reports No. 106), FAO, Rome.

[18] Hurlin, C. (2003) Econométrie des variables qualitatives. Cours de maîtrise d'économétrie, France Université d'Orléans, Orléans, 59 p.

[19] Sidibé, A. (2005) Farm-Level Adoption of Soil and Water Conservation Techniques in Northern Burkina Faso. Agricultural Water Management, 71, 211-224. https://doi.org/10.1016/j.agwat.2004.09.002

[20] Koutou, M., Ouedraogo, M., Nacro, H.B. and Lepage, M. (2007) Déterminants de l'adoption du zaï forestier et perspectives de valorisation de la technique (province du Yatenga, Burkina Faso). Actes des JSIRAUF, Hanoi.

[21] Sarma, C. (1989) Un exemple d'application du modèle Logit: L'investissement immobilier des couples non mariés. Économie \& Prévision, 91, 109-112. https://doi.org/10.3406/ecop.1989.5145

[22] Ngondjeb, Y., Nje, P. and Havard, M. (2011) Déterminants de l'adoption des techniques de lutte contre l'érosion hydrique en zone cotonnière du Cameroun. Revue d' Elevage et de Médecine Vétérinaire des Pays Tropicaux, 64, 9-19. https://doi.org/10.19182/remvt.10120

[23] Batamoussi, H.M., Moumouni, I. and Tokore Orou Mere, S.B.J. (2015) Contribution à l'amélioration des pratiques paysannes de production durable de coton (Gossypium hirsutum) au Bénin: Cas de la commune de Banikoara. International Journal of Biological and Chemical Sciences, 9, 2401-2413. https://doi.org/10.4314/ijbcs.v9i5.12

[24] Bambara, D., Zoundi, J.S. and Tiendrébéogo, J.-P. (2008) Association céréale/ 
légumineuse et intégration agriculture-élevage en zone soudano-sahélienne. Cahiers Agricultures, 17, 297-301.

[25] N’Goran, K.E., Kassin, K.E., Zohouri, G.P., N'Gbesso, M. and Yoro, G.R. (2011) Performances agronomiques des associations culturales igname-légumineuses Alimentaires. Journal of Applied Biosciences, 43, 2915-2923.

[26] Soltner, D. (2003) Les bases de la production végétale Tome 1. Le sol et son amélioration 14ème édition: Collection sciences et techniques agricoles.

[27] Lompo, F., Segda, Z., Gnankambary, Z. and Ouandaogo, N. (2009) Influence des phosphates naturels sur la qualité et la biodégradation d'un compost de pailles de maïs. Tropicultura, 27, 105-109.

[28] Weill, A. and Duval, J. (2009) Equiterre, Module 7 Amendements et fertilisation, Chapitre 12 les amendements organiques: Fumiers et compost, Manuscrit du guide de gestion globale de la ferme maraichère biologique et diversifiée.

https://www.agrireseau.net/agriculturebiologique/documents/MARAI_Chapitre_12 Amendements.pdf

[29] Jemai, I., Guirat, S.B., Aissa, N.B., Jedidi, N. and Gallali, T. (2011) Effet de l'amendement par fumier de ferme et par compost d'ordures ménagères sur la restauration d'un sol argileux de pleine sous climat semi-aride tunisien. Andudes et Gestion des Sols, 18, 271-285.

[30] Roose, E., Kabore, V. and Guenat, C. (1995) Le zaï, une technique traditionnelle africaine de réhabilitation des terres dégradées de la région soudano-sahélienne (Burkina Faso). In: Pontanier, R., M'Hiri, A., Akrimi, N., Aronson, J. and Le Floc'h, E., Eds., L homme peut-il refaire ce qu'il a défait, Eurotext, John Libbey, Paris, 249-265.

[31] Dugué, P., Autfray, P., Blanchard, M., Djamen, P., Landry, A., Girard, P., Olina, J.P., Ouedraogo, S., Sissoko, F. and Vall, E. (2012) L'agroécologie pour l'agriculture familiale dans les pays du sud: Impasse ou voie d'avenir? Le cas des zones de savane cotonnière de l'Afrique de l'Ouest et du Centre. Colloque René Dumont revisité et les politiques agricoles africaines. Fondation René Dumont, Paris.

[32] Fentie, D., Fufa, B. and Bekele, W. (2013) Determinants of the Use of Soil Conservation Technologies by Smallholder Farmers: The Case of Hulet Eju Enesie District, East Gojjam Zone, Ethiopia. Asian Journal of Agricultural and Food Sciences, 1, 2321-1571.

[33] Kebede, W. and Mesele, N. (2014) Farmers' Adoption of Soil and Water Conservation Technology: A Case Study of the Bokole and Toni Sub-Watersheds, Southern Ethiopia. Journal of Sciences Development, 2, 35-48.

[34] Lapar, A.L. and Pandey, S. (1999) Adoption of Soil Conservation: The Case of the Philippine Uplands. Agricultural Economics, 21, 241-256.

https://doi.org/10.1016/S0169-5150(99)00028-6

[35] Zoungrana, C. (2004) Adoption des techniques de conservation des sols et lutte contre la pauvreté au Yatenga. Mémoire de D.E.A., Université de Ouagadougou, Burkina Faso.

[36] Sangaré, S. (2002) Evaluation des performances agro-écologiques des techniques de lutte contre la désertification dans les provinces du Passoré et du Yatenga. Casdu zaï, de la demi-lune et du tapis herbacé. Mémoire de fin d'études, Université Polytechnique de Bobo-Dioulasso-Institut du Développement Rural (UPB-IDR).

[37] Zougmore, R., Guillobez, S., Kambou, N.F. and Son, G. (2000) Runoff and Sorghum Performance as Affected by the Spacing of Stone Lines in the Semiarid Sahelian Zone. Soil \& Tillage Research, 56, 175-183. 
https://doi.org/10.1016/S0167-1987(00)00137-9

[38] Koulibaly, B., Traoré, O., Dakuo, D. and Zombré, P.N. (2009) Effets des amendements locaux sur les rendements, les indices de nutrition et les bilans culturaux dans un système de rotation coton-maïs dans l'ouest du Burkina Faso. Biotechnology, Agronomy, Society and Environment, 13, 103-111.

[39] M'Biandoun, M., Thèze, M. and Abba, A. (2003) Maintien ou amélioration du potentiel productif des sols en région soudano-sahélienne du Nord-Cameroun. In: Jamin, J.-Y., Lamine Boukar, S. and Floret, C., Eds., CiradPrasac, hal-00135459, 11 p.

[40] Asimi, S. (2009) Influence des modes de gestion de la fertilité des sols sur l'activité microbienne dans un système de cultures de longue durée au Burkina Faso. Thèse de doctorat, Université Polytechnique de Bobo Dioulasso, Burkina Faso. 